\title{
Hubungan Antara Status Gizi (IMT) dengan Usia Menarche pada Remaja Putri Usia 13-14 Tahun di SMPN 1 Pace Kecamatan Pace Kabupaten Nganjuk
}

\author{
(the relationship between nutritional status with age of menarche in young women aged \\ 13-14 years) \\ Sumy Dwi Antono \\ Poltekkes Kemenkes Malang \\ Prodi Kebidanan Kediri Jl.KH.Wakhid Hasyim 64 B Kediri
}

\begin{abstract}
The average of menarche young women continoued to decline on average about 3-4 months every 10 years. The shift of the age of menarche to younger age can cause emotional stress, the risk of breast cancer, pregnancy is noy on purpose. The purpose of this research is to know the relationship between nutritional status with age of menarche in young women aged 13-14 years. The type of this research use cross sectional research design. Sampling technique of this research used proportional stratified random sampling which the research took a random strata in the population, for this research the reseacher using the lottery draw. The researcher abtained samples of 76 responden of total student population of 96. The analysis data of this research is Spearman Rank. The result of the analysis data shows that there is no relationship between nutritional status with age of menarche which the value $t_{\text {count }}=0,647$ less than $t_{\text {table }}=1,995$. For this research the researcher gives suggestion to the next researcher to develop the factor social media that can influence the age of menarche in girls forther.
\end{abstract}

Keywords : nutritional status, age of menarche, young women

\section{Latar Belakang}

Masa remaja adalah masa peralihan dari masa kanak-kanak ke dewasa. Batasan usia remaja menurut World Health Organization (WHO) (2007) adalah 12 sampai 24 tahun. Remaja merupakan tahapan seorang dimana dia berada di antara fase anak dan dewasa yang ditandai dengan perubahan fisik, perilaku, kognitif, biologis, dan emosi yang merupakan periode pematangan organ reproduksi manusia, dan sering disebut masa pubertas (Efendi, 2009).

Masa pubertas seorang perempuan ditandai dengan menarche (menstruasi pertama). Menarche adalah haid pertama kali yang dialami seorang perempuan yang merupakan ciri khas kedewasaan seorang perempuan, sebagai pertanda masa peralihan dari masa anak menuju masa dewasa. Selain ditandai dengan menarche, masa pubertas ditandai juga dengan adanya ciri-ciri sekunder, yaitu tumbuhnya rambut ketiak, tumbuhnya rambut pubis, dan pembesaran payudara. Jadi menarche pada seorang wanita mengindikasikan bahwa alat reproduksinya mulai berfungsi. Saat ini kebanyakan seorang perempuan mengalami menstruasi pertama menarche lebih cepat.

Berdasar hasil penelitian yang dilakukan di SMPN 155 Jakarta tahun 2011 tentang Faktor-faktor yang Berhubungan dengan Usia Menarche pada Remaja Putri di SMPN 155 Jakarta Tahun 2011 menunjukkan bahwa responden yang memiliki usia menarche cepat dan status gizi lebih dan resiko gizi lebih adalah sebanyak 13 orang $(33,3 \%)$, responden yang memiliki usia menarche cepat dan status gizi kurang dan baik adalah sebanyak $26(66,7 \%)$ orang. Responden yang memiliki usia menarche normal dengan status gizi lebih dan resiko lebih adalah sebanyak 7 orang $(12,3 \%)$ dan 
responden yang memiliki usia menarche normal yaitu usia 12-13 tahun dengan status gizi kurang serta baik adalah sebanyak 50 orang $(87,7 \%)$ (Derina, 2011).

Hasil penelitian yang dilakukan pada siswi kelas VIII SMP Muhammadiyah 5 Pucang Surabaya menunjukkan bahwa responden dengan status gizi gemuk yaitu 30 siswi (75\%) mengalami menarche cepat, sedangkan responden dengan status gizi normal yaitu 25 siswi $(65,79 \%)$ mengalami menarche normal. Dari hasil analisis menggunakan uji korelasi Spearman diperoleh nilai signifikan 0,000 , karena $\rho=0,000<\alpha=0,05$ maka Ho ditolak yang berarti ada pengaruh status gizi terhadap terjadinya menarche (Badriyah, 2011).

Berdasarkan hasil penelitian pada siswi kelas VII dan kelas VIII SMPN 11 Semarang diperoleh informasi bahwa persentase seluruh siswi (100\%) kelas VII dan kelas VIII yang menjadi responden tidak pernah mendapat paparan audio visual berupa menonton atau membaca majalah porno. Hal ini diperkuat dari penelitian sebelumnya yang mengatakan bahwa lingkungan berpengaruh pada waktu terjadinya menarche. Remaja putri yang tinggal di kota mendapat fasilitas hiburan seperti internet, atau majalah/film porno sehingga mempercepat menarche dibandingkan dengan remaja putri yang tinggal di pedesaan (Kusuma, 2012).

Berdasarkan hasil studi pendahuluan yang dilakukan di SMPN 1 Pace didapatkan dari 20 siswi terdapat 9 siswi $(45 \%)$ mengalami menstruasi pertama usia 11 tahun, 11 siswi (55\%) mengalami menstruasi pertama usia 12-13 tahun.

Fenomena di atas cukup banyak kita jumpai dan pasti ada faktor-faktor yang mempengaruhi hal tersebut. Diantaranya adalah faktor suku, genetik, gizi, sosial, ekonomi, dll. Usia anak perempuan mengalami menarche bervariasi antara usia 10-15 tahun (Fairus, dkk, 2011). Usia rata-rata menarche terus menurun rata-rata sekitar 3-4 bulan setiap 10 tahun
(Prawirohardjo, 2011). Seharusnya menarche terjadi pada wanita di usia 1213 tahun. Sedangkan pada dekade 60-an, kebanyakan wanita pertama kali mengalami menstruasi pada usia 15-16 tahun, pada abad ke 21 menarche bergeser ke usia lebih muda. Membaiknya standar kehidupan berdampak pada pergeseran usia menarche ke usia yang lebih muda. Pergeseran usia menarche ke usia lebih muda bisa menyebabkan stress emosional, risiko terkena kanker payudara (Susanti dan Sunarto, 2012), kehamilan yang tidak disengaja (Martaadisoebrata, 2005). Hal ini terjadi karena status gizi dan kesehatan yang semakin baik. Wanita yang bergizi baik mempunyai kecepatan pertumbuhan yang lebih tinggi pada masa sebelum pubertas (prapubertas) dibandingkan dengan remaja yang kurang gizi. Penelitian ini bertujuan untuk menganalisa hubungan antara status gizi (IMT) dengan usia menarche pada remaja putri usia 1314 tahun di SMPN 1 Pace Kecamatan Pace Kabupaten Nganjuk.

\section{Metode Penelitian}

Desain penelitian yang digunakan adalah rancangan penelitian analitik dengan pendekatan cross-sectional dimana variabel bebas yaitu status gizi dan variabel terikat yaitu usia menarche yang diukur pada waktu yang bersamaan. Populasi dalam penelitian ini adalah seluruh siswi SMPN 1 Pace usia 13-14 tahun yang sudah mengalami menstruasi sejumlah 96 siswi. Sampel yang digunakan yaitu sebagian siswi perempuan usia 13-14 tahun SMPN 1 Pace yang sudah mengalami menstruasi. Besar sampel menggunakan tabel Normogram Harry King dengan taraf kesalahan 5\%, sehingga didapatkan besar sampel 75 siswi. Teknik pengambilan sampel menggunakan Proportional Stratified Random Sampling. Teknik analisa data dengan uji Spearman Rank. 


\section{Hasil Penelitian}

1. Status gizi pada remaja putri usia 13-14 tahun di SMPN 1 Pace

Distribusi status gizi pada remaja putri usia 13-14 tahun di SMPN 1 Pace dapat dilihat pada tabel dibawah ini :

Tabel 1 Distribusi Status Gizi pada Remaja Putri Usia 13-14 Tahun di SMPN 1 Pace

\begin{tabular}{lll}
\hline Kategori & $\begin{array}{c}\text { Jumlah } \\
(\mathbf{n})\end{array}$ & $\begin{array}{c}\text { Presentase } \\
(\boldsymbol{\%})\end{array}$ \\
\hline Kurang & 9 & 11,8 \\
Normal & 50 & 65,8 \\
Lebih & 17 & 22,4 \\
\hline & Total & 100 \\
\hline
\end{tabular}

Sumber: Data primer hasil penelitian tanggal 14 Juli 2014

Berdasarkan hasil penelitian yang dilakukan pada remaja putri usia 13-14 tahun di SMPN 1 Pace seperti terlihat pada Tabel 1 bahwa lebih dari setengah responden $65,8 \%$ (50 siswi) berstatus gizi normal.

2. Usia menarche pada remaja putri usia 13-14 tahun di SMPN 1 Pace

Distribusi usia menarche pada remaja putri usia 13-14 tahun di SMPN 1 Pace dapat dilihat pada tabel dibawah ini :

\section{Tabel 2 Distribusi Usia Menarche pada Remaja Putri Usia 13-14 Tahun di SMPN 1 Pace}

\begin{tabular}{lll}
\hline Kategori & $\begin{array}{c}\text { Jumlah } \\
(\mathbf{n})\end{array}$ & $\begin{array}{c}\text { Presentase } \\
(\boldsymbol{\%})\end{array}$ \\
\hline Cepat & 11 & 14,5 \\
Normal & 63 & 82,9 \\
Lambat & 2 & 2,6 \\
\hline & Total & 100 \\
\hline
\end{tabular}

Sumber: Data primer hasil penelitian tanggal 14 Juli 2014

Berdasarkan hasil penelitian yang dilakukan pada remaja putri usia 13-14 tahun di SMPN 1 Pace seperti terlihat pada Tabel 2 dapat dijelaskan bahwa sebagian besar responden memiliki usia menarche normal 82,9\% (63 siswi).

\section{Hubungan Antara Status Gizi dengan Usia Menarche pada Remaja Putri Usia 13-14 Tahun di SMPN 1 Pace}

Hasil analisis dari status gizi dengan usia menarche pada remaja putri usia 1314 tahun dapat dilihat pada tabel dibawah ini:

Tabel 3 Tabulasi Silang Status Gizi dengan Usia Menarche pada Remaja Putri Usia 13-14 Tahun

\begin{tabular}{llllllll}
\hline \multirow{2}{*}{ Status gizi } & \multicolumn{6}{c}{ Usia Menarche } & \multirow{2}{*}{ Jumlah } \\
\cline { 2 - 7 } & \multicolumn{3}{c}{ Cepat } & \multicolumn{3}{c}{ Normal } & \multicolumn{2}{c}{ Lambat } & \\
\hline Kurang & 0 & - & 8 & 10,5 & 1 & 1,3 & 9 \\
Normal & 1 & 1,3 & 48 & 63,2 & 1 & 1,3 & 50 \\
Lebih & 10 & 13,2 & 7 & 9,2 & - & - & 17 \\
Jumlah & 11 & 14,5 & 63 & 82,9 & 2 & 2,6 & 76 \\
\hline
\end{tabular}

Sumber: Data primer hasil penelitian tanggal 14 Juli 2014

Berdasarkan Tabel 3 dapat dijelaskan bahwa lebih dari setengah responden yaitu $63,2 \%$ (48 siswi) dengan status gizi normal dan usia menarche normal.

\section{Pembahasan}

1. Status gizi pada remaja putri usia 13-14 tahun

Data hasil penelitian memperlihatkan bahwa lebih dari setengah responden yaitu sebesar 50 siswi $(65,8 \%)$ berstatus gizi normal, sebagian kecil responden yaitu sebesar 9 siswi $(11,8 \%)$ berstatus gizi kurang, dan sebagian kecil responden yaitu sebesar 17 siswi $(22,4 \%)$ berstatus gizi lebih.

Responden yang dalam kategori status gizi normal lebih dari setengah responden dan responden yang masuk dalam kategori status gizi lebih yaitu sebagian kecil respnden, hal ini disebabkan karena saat ini sosial ekonomi masyarakat semakin membaik. Dengan membaiknya sosial ekonomi masyarakat, makanan yang dikonsumsi remaja tentu makanan yang banyak mengandung zat gizi dan vitamin yang akan mempengaruhi 
pertumbuhan dan perkembangannya, sehingga status gizi remaja akan semakin membaik juga. Karena disini remaja merupakan masa peralihan dari masa anak menuju masa dewasa dimana pada masa remaja ini terjadi pertumbuhan fisik, mental dan emosional yang sangat cepat.

Pada remaja kebiasaan ikut-ikutan dengan teman sebayanya merupakan salah satu faktor yang dapat sangat mempengaruhi keadaan pada gizi remaja seperti sering makan diluar rumah bersama teman-teman. Selain itu faktor keturunan atau genetik juga bisa mempengaruhi status gizi remaja. Remaja yang memiliki orang tua gemuk, kemungkinan besar remaja tersebut juga gemuk, ataupun sebaliknya.

Menurut Dewi, dkk (2013) Pengaruh lingkungan penting terhadap perilaku remaja. Kebiasaan ikut-ikutan dengan teman sekelompoknya atau teman sebayanya merupakan salah satu masalah yang dapat terjadi pada remaja. Bila kebiasaan remaja buruk seperti minumminuman beralkohol, merokok, begadang tiap malam sangat mempengaruhi keadaan gizi remaja tersebut Faktor keturunan juga berperan dalam mempengaruhi status gizi remaja. Remaja yang mempunyai orangtua gemuk, maka kemungkinan remaja tersebut juga bisa mengalami kegemukan. Ataupun sebaliknya, bila orangtua kurus, maka remaja tersebut juga mengalami hal yang sama.

Berdasarkan penelitian tentang Pengaruh Status Gizi Remaja Terhadap Usia Menarche pada Siswi SDN Dukuh Menanggal Surabaya yang dilakukan oleh Putri Kusnita dan Damarati (2012) bahwa terdapat 23 siswi $(63,9 \%)$ dari 36 siswi SDN Dukuh mempunyai status gizi baik.

Berdasarkan hasil penelitian dan beberapa penelitian orang lain dapat dilihat bahwa banyak responden yang mempunyai status gizi normal karena semakin membaiknya standar kehidupan masyarakat, pengaruh dari teman sekelompok atau teman sebaya dan faktor genetik.

\section{Usia menarche pada remaja remaja putri usia 13-14 tahun}

Data hasil penelitian yang dilakukan pada remaja putri usia 13-14 tahun di SMPN 1 Pace memperlihatkan bahwa sebagian besar responden memiliki usia menarche normal yaitu sebanyak 63 siswi (82,9\%), sebagian kecil responden memiliki usia menarche cepat yaitu sebanyak 11 siswi (14,5\%), dan sebagian kecil responden memiliki usia menarche lambat yaitu sebanyak 2 siswi $(2,6 \%)$.

Usia saat seorang anak perempuan mendapatkan menstruasi pertama sangat bervariasi. Usia normal bagi seorang perempuan mendapatkan menstruasi untuk pertama kalinya yaitu pada usia 1213 tahun. Saat ini kecenderungan anak perempuan mendapatkan menstruasi pertama kali pada usia yang normal. Ada yang berusia 12 tahun saat pertama kali mendapatkan menstruasi ada juga yang mendapatkan menstruasi pada usia 13 tahun. Banyak faktor yang mempengaruhi cepat lambatnya menarche diantaranya adalah faktor sosial, ekonomi, lingkungan, genetik,suku, dan gizi. Pada penelitian ini sebagian besar responden mendapatkan usia menarche normal dan sebagian kecil responden memiliki usia menarche cepat, hal ini disebabkan karena dengan mengkonsumsi makanan yang cukup gizi dan teratur remaja akan tumbuh sehat, sehingga akan mempengaruhi pertumbuhan dan fungsi organ tubuh termasuk organ reproduksi. Karena makanan merupakan slah satu kebutuhan yang pokok bagi manusia untuk tumbuh dan berkembang. Selain itu, hal ini mungkin disebabkan karena pengaruh media sosial seperti radio, televisi, majalah, dan internet yang ada dilingkungan sekitarnya sehingga berdampak pada tingkat kesuburan dan kematangan hormon yang terdapat dalam tubuh remaja tersebut sehingga remaja akan mengalami kematangan seksual yang lebih cepat sehingga perubahan fisik 
berkembang secara cepat juga dan akan berdampak pada terjadinya menarche.

Menurut Karis Amalia Derina (2011) yang berperan dalam derajat kesehatan ada 4 faktor utama yaitu perilaku, lingkungan, genetik, dan akses ke pelayanan kesehatan. Bila percepatan usia menarche dianggap sebagai perubahan yang berhubungan dengan derajat kesehatan maka secara garis besar faktor yang mempercepat terjadinya usia menarche yaitu perilaku yang dalam hal ini bisa dicerminkan dari status gizi responden, genetik yang dapat dilihat dari usia menarche ibu, akses pelayanan kesehatan sehingga responden dalam keadaan sehat, dan yang tidak kalah penting adalah faktor lingkungan.

Menurut Putri Kusnita dan Damarati (2012) Percepatan proses menarche juga dipengaruhi oleh perubahan hormon steroid estrogen dan progesteron yang mempengaruhi pertumbuhan endometrium, semakin baik gizi siswi maka semakin cepat siswi akan mengalami menarche.

\section{Hubungan Status Gizi dengan Usia Menarche pada Remaja Putri Usia 13-14 Tahun}

Data hasil penelitian memperlihatkan bahwa dari 76 responden lebih dari setengah responden yaitu 48 siswi $(63,2 \%)$ dengan status gizi normal dan usia menarche normal juga.

Setelah dilakukan pengujian hipotesis dengan Uji Korelasi Spearmen Rank didapatkan hasil $\mathrm{t}$ hitung $<\mathrm{t}$ tabel artinya tidak ada hubungan antara status gizi dengan usia menarche pada remaja putri usia 13-14 tahun.

Hal ini dikarenakan banyak faktor yang mempengaruhi cepat lambatnya menarche selain dari faktor gizi diantaranya faktor sosial, ekonomi, lingkungan, genetik, media sosial dan suku. Pada penelitian ini banyak remaja yang mempunyai status gizi normal, sehingga banyak remaja yang mendapatkan usia menarche yang normal juga. Selain itu, faktor media sosial seperti televisi, radio, majalah, dan internet juga dapat mempengaruhi cepat lambatnya usia menarche pada remaja perempuan. Sekarang ini banyak masyarakat yang sudah mempunyai televisi yang dapat menayangkan sinetron-sinetron yang menampilkan anak-anak berperan sebagai orang dewasa dalam sinetron percintaan remaja maupun orang dewasa, sehingga terdapat kebiasaan para remaja untuk menonton sinetron yang sangat mendukung untuk terjadinya pematangan alat reproduksinya, karena biasanya setelah menonton mereka memiliki keinginan untuk menjadi peran seperti artis yang diidolakannya.

Berdasarkan penelitian oleh Dono Anggar Kusuma (2012) tentang hubungan beberapa faktor siswi dengan kejadian menarche pada remaja awal didapatkan bahwa persentase seluruh siswi (100\%) kelas VII dan kelas VIII yang menjadi responden tidak pernah mendapat paparan audio visual berupa menonton atau membaca majalah porno. Hal ini diperkuat dari penelitian sebelumnya yang mengatakan bahwa lingkungan berpengaruh pada waktu terjadinya menarche. Remaja putri yang tinggal di kota mendapat fasilitas hiburan seperti internet, atau majalah/film porno sehingga mempercepat menarche dibandingkan dengan remaja putri yang tinggal di pedesaan.

Dari hasil penelitian juga didapatkan bahwa dari 76 responden sebagian kecil responden yaitu 10 siswi $(13,2 \%)$ dengan status gizi lebih dan usia menarche cepat, hal ini terjadi karena dengan mengkonsumsi makanan yang bergizi dan teratur dapat mempengaruhi pertumbuhan, sistem kerja hormon dalam tubuh dan fungsi organ tubuh pada remaja tersebut termasuk organ reproduksi. Makanan yang banyak mengandung lemak, protein hewani, kalsium, dan lain sebagainya akan mempengaruhi sistem kerja hormon yang akhirnya akan berdampak pada pertumbuhan dan perkembangan sistem 
reproduksi. Misalnya lemak akan merangsang pematangan folikel dan pembentukan estrogen. Protein hewani akan meregulasi pertumbuhan somatik dan kematangan organ reproduksi.

Menurut Susanti dan Sunarto (2012) terjadinya menarche dilihat dari sistem kerja hormon yang ada di tubuh yaitu dengan mengkonsumsi makanan tinggi lemak akan berakibat pada penumpukan lemak dalam jaringan adiposa yang berkorelasi positif dengan peningkatan kadar leptin. Leptin ini akan memicu pengeluaran hormon GnRH (Gonadotropin Releazing Hormone) yang selanjutnya mempengaruhi pengeluaran FSH (Follicle Stimulating Hormone) dan LH (Luteinizing Hormone) dalam merangsang pematangan folikel dan pembentukan estrogen.

Menurut Susanti dan Sunarto (2012) Asupan protein hewani berlebih terutama berasal dari susu dan olahannya akan merangsang sekresi insulin dan Insulin Like Growth Factor 1 (IGF-1). Insulin tersebut akan menekan IGF pengikat protein 1, kemampuan IGF-1 berpengaruh terhadap produksi somatopedin, yaitu suatu fasilitator pertumbuhan yang diproduksi oleh hati sebagai hormon pertumbuhan yang berfungsi sebagai penggerak utama kematangan seksual. Asupan protein hewani akan meningkatkan fase luteal. Akan tetapi jika dikonsumsi secara berlebihan akan berpengaruh terhadap peningkatan frekuensi puncak LH dan mengalami pemanjangan fase folikuler yang akan mempercepat seseorang untuk memasuki awal pubertas. Lain halnya dengan protein nabati yang kaya akan isoflavon berhubungan dengan keterlambatan usia menarche. Isoflavon dikaitkan dengan efek antiekstrogenik yang mampu menggantikan estradiol untuk berinteraksi langsung dengan reseptor estrogen a (Era gene). Kondisi inilah yang akan mengacaukan gen ERa untuk melakukan transkripsi gen sebagai pemicu awal pubertas. Adapun keterlibatan asupan mikronutrien yaitu kalsium, terutama pada susu yang mempengaruhi jumlah estrogen dan faktor pertumbuhan dalam mengirimkan sinyal fisiologis untuk regulasi pertumbuhan somatik dan kematangan organ reproduksi.

Menurut Susanti dan Sunarto (2012) Serat pada makanan terutama jenis serat larut air berpengaruh terhadap penurunan kadar kolesterol. Berkurangnya jumlah kolesterol dapat menurunkan kadar leptin dalam darah. Leptin berpengaruh terhadap sekresi GnRH dan hormon estrogen yang digunakan untuk mengawali pubertas. Pengaruh serat terhadap kadar kolesterol dikaitkan dengan metabolisme asam empedu. Serat makanan dapat menyerap asam empedu yang disintetis dari kolesterol di dalam hati.

Kalsium yang terkandung dalam susu akan mengirimkan sinyal untuk mengatur pertumbuhan somatik dan mekanisme lain yang berhubungan dengan kematangan reproduksi. IGF-1 merupakan bagian dari protein susu yang strukturnya mirip insulin. Dan terlibat dalam pertumbuhan somatik dan kematangan reproduksi, serta berkorelasi dengan asupan kalsium dan susu untuk mempercepat usia menarche menurut Susanti dan Sunarto (2012).

\section{Simpulan}

1. Status gizi remaja putri usia 13-14 tahun di SMPN 1 Pace lebih dari setengah responden mempunyai status gizi normal.

2. Usia menarche remaja putri usia 1314 tahun di SMPN 1 Pace sebagian besar responden masuk dalam kategori menarche normal.

3. Tidak ada hubungan antara status gizi dengan usia menarche pada remaja putri usia 13-14 tahun di SMPN 1 Pace karena lebih dari setengah responden dengan status gizi normal dan usia menarche normal.

\section{Saran}

\section{Bagi Tempat Penelitian}

1. Kepada pihak sekolah untuk memantau perkembangan kesehatan 
reproduksi siswi-siswi SMPN 1 Pace dengan membuat daftar siswi yang sudah mengalami menstruasi. Mengadakan penyuluhan tentang kesehatan reproduksi, terutama masalah kesiapan menghadapi menarche.

\section{Bagi Institusi Pendidikan}

Dalam penelitian selanjutnya diharapkan lebih mengembangkan penelitiannya mengenai faktor-faktor lain yang mempengaruhi usia menarche pada remaja putri terutama faktor audio visual.

\section{Daftar Pustaka}

Adriani, M., dan Bambang W. 2012. Peran Gizi dalam Siklus Kehidupan. Jakarta: Kencana Prenada Media Group.

Arikunto, S. 2006. Prosedur Penelitian Suatu Pendekatan Praktik (Edisi Revisi VI). Jakarta: Rineka Cipta.

Badriyah, dan Sulastri. 2011. Pengaruh Status Gizi Terhadap Terjadinya Menarche Pada Siswi Kelas VIII SMP Muhammadiyah 5 Pucang Surabaya. Jurnal Penelitian Kesehatan Suara Forikes. Halaman: 1-56.

Derina, K. A. 2011. Faktor-faktor yang Berhubungan dengan Usia Menarche pada Remaja Putri di SMPN 155 Jakarta Tahun 2011.

Dewi, A.B.F.K, dkk. 2013. Ilmu Gizi untuk Praktisi Kesehatan. Yogyakarta: Graha Ilmu.

Efendi, F. 2009. Keperawatan Kesehatan Komunitas:Teori dan Praktik dalam Keperawatan. Jakarta: Salemba Medika.

Fairus, M., dan Prasetyowati. 2011. Buku Saku Gizi dan Kesehatan Reproduksi. Jakarta: EGC.

Hermawanto, H. 2010. Menyiapkan Karya Tulis Ilmiah. Jakarta : TIM

Hidayat, A. 2009. Metode Penelitian Kebidanan dan Teknik Analisis Data. Jakarta: Salemba.
Irianto, D. P. 2007. Panduan Gizi Lengkap Keluarga dan Olahragawan. Yogyakarta: Andi.

Kanisius. 2009. Bebas Masalah Berat Badan. Yogyakarta: Kanisius.

Kusnita, P. dan Damarti. Pengaruh Status Gizi Remaja Terhadap Usia Menarche pada siswi SDN Dukuh Menanggal Surabaya. http://digilib.unipasby.ac.id/files/disk 1/3/gdlhub--putrikusni-121-1damarati.pdf. Diakses tanggal 21 Februari 2014.

Kusuma, D. A. 2012. Hubungan Beberapa Faktor Siswi dengan Kejadian Menarche Pada Remaja Awal di SMPN 11 Kota Semarang Bulan JuniAgustus 2012. Jurnal Kesehatan Masyarakat 2013. Halaman: 1-10.

Notoatmodjo, S. 2010. Metodologi Penelitian Kesehatan. Jakarta: Rineka Cipta.

Nursalam. 2008. Konsep dan Penerapan Metodologi Penelitian Ilmu Keperawatan Pedoman Skripsi, Tesis, dan Instrumen Penelitian Keperawatan. Jakarta: Salemba.

Martaadisoebrata, Djamhoer. 2005. Obstetri dan Ginekologi Sosial. Jakarta: Yayasan Bina Pustaka Sarwono Prawirohardjo.

Paath, E.F, dkk. 2005. Gizi dalam Kesehatan Reproduksi. Jakarta: EGC.

Prawirohardjo, S. 2011. Ilmu Kandungan. Jakarta: PT Bina Pustaka Sarwono Prawirohardjo.

Proverawati, A., dan Siti A. 2009. Buku Ajar Gizi Untuk Kebidanan. Yogyakarta: Nuha Medika.

Saifuddin, A. B. 2005. Ilmu Kandungan. Jakarta: Yayasan Bina Pustaka Sarwono Prawirohardjo.

Sibagariang, E. E., dkk. 2010. Kesehatan Reproduksi Wanita. Jakarta: Trans Info Media

Soetjiningsih. 2004. Tumbuh Kembang Remaja Dan Permasalahannya. Jakarta: Sagung Seto.

Sugiyono. 2010. Statistika untuk Penelitian. Bandung: Alfabet. 
Sukarni, I., dan Wahyu K. 2013. Buku Ajar Keperawatan Maternitas. Yogyakarta: Nuha Medika.

Supariasa, I D. N., dkk, 2012. Penilaian Status Gizi. Jakarta: EGC.

Supranto. 2007. Teknik Sampling untuk Survey \& Eksperimen. Jakarta: Rineka Cipta.

Susanti, A. V., dan Sunarto. 2012. Faktor Risiko Kejadian Menarche Dini pada Remaja di SMPN 30 Semarang. Journal of Nuttrition College. Halaman 1-12.

Tim Penulis Poltekkes Depkes Jakarta I. 2010. Kesehatan Remaja: Problem dan Solusinya. Jakarta: Salemba Medika. 